\title{
Persistent fever and right hypochondrium pain
}

\author{
Thomas Roland, ${ }^{1}$ Halil Yildiz, ${ }^{2}$ Bernard Vandercam, ${ }^{1}$ Lucie Pothen ${ }^{2}$
}

${ }^{1}$ Infectiology, Cliniques Universitaires Saint-Luc, Bruxelles, Belgium Internal Medicine, Cliniques Universitaires Saint-Luc, Bruxelles, Belgium

Correspondence to Dr Halil Yildiz, halil.yildiz@ uclouvain.be

Accepted 19 June 2017

\section{CrossMark}

To cite: Roland T, Yildiz $\mathrm{H}$, Vandercam $\mathrm{B}$, et al. BMJ Case Rep Published Online First: [please include Day Month Year]. doi:10.1136/bcr-2017221254

\section{DESCRIPTION}

A 39-year-old patient was admitted to our hospital for 10 days fever (up to $40^{\circ} \mathrm{C}$ ) with pain in the right hypochondrium. Abdominal echography performed at the onset of symptoms was normal. Blood tests showed C-reactive protein $311 \mathrm{mg} / \mathrm{L}$, leucocytes count $24 \times 10^{9} / \mathrm{L}$ (neutrophils count at $19,29 \times 10^{9} / \mathrm{L}$ ), bilirubin $1.1 \mathrm{mg} / \mathrm{dL}$, lactate dehydrogenase (LDH) $254 \mathrm{U} / \mathrm{L}$, aspartate aminotransferase (ASAT) $67 \mathrm{U} / \mathrm{L}$, alanin aminotransferase (ALAT) $66 \mathrm{U} / \mathrm{L}$, gammaGlutamyltransferase (gGT) $79 \mathrm{U} / \mathrm{L}$ and alkaline phosphatase 221U/L. Chest X-ray showed an infiltrate in the right lung base. A diagnosis of pneumonia was made and treatment with cefuroxime started. Since fever and right hypochondrium pain persisted despite antibiotherapy for 5 days, abdominal CT scan was performed, which demonstrated a large hepatic mass of $10 \times 7 \mathrm{~cm}$ (figure 1). Percutaneous drainage revealed a thick and brown liquid; 'chocolate-like' (figure 2). Complementary information came from anamnesis: the patient usually lives in Cambodia and he has had dysentery 3 months ago. Clinical and biological evolution was well under metronidazole $500 \mathrm{mg}$ three times a day for 10 days. Entamoeba serology (antibody detection with indirect fluorescent antibody technique) came back positive (1/800). A diagnosis of amoebic abscess was retained and the patient completely recovered at the end of the treatment (paromomycin for 7 days after metronidazole). Amoebic liver abscess is caused by Entamoeba histolytica. ${ }^{1}$ Antibiotic such as metronidazole is the usual treatment for liver abscess. Paromomycin has also to be taken to prevent the recurrence. In rare cases, the abscess may need to be drained to relieve some of the abdominal pain (abscesses greater than $5 \mathrm{~cm})^{2}$

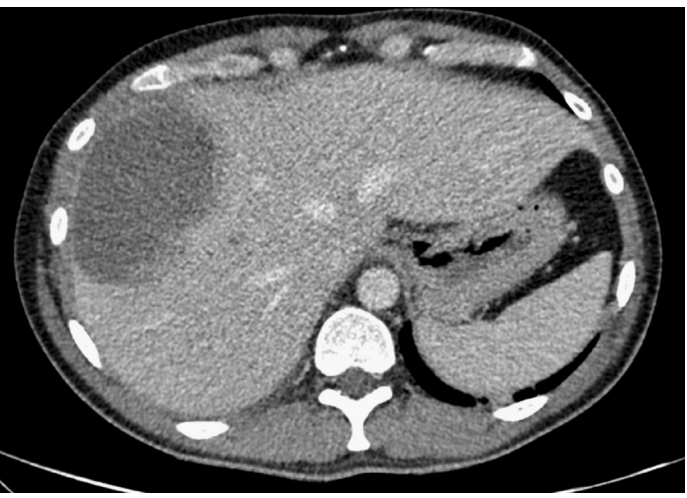

Figure 1 Abdominal CT scan showing a large hepatic mass.

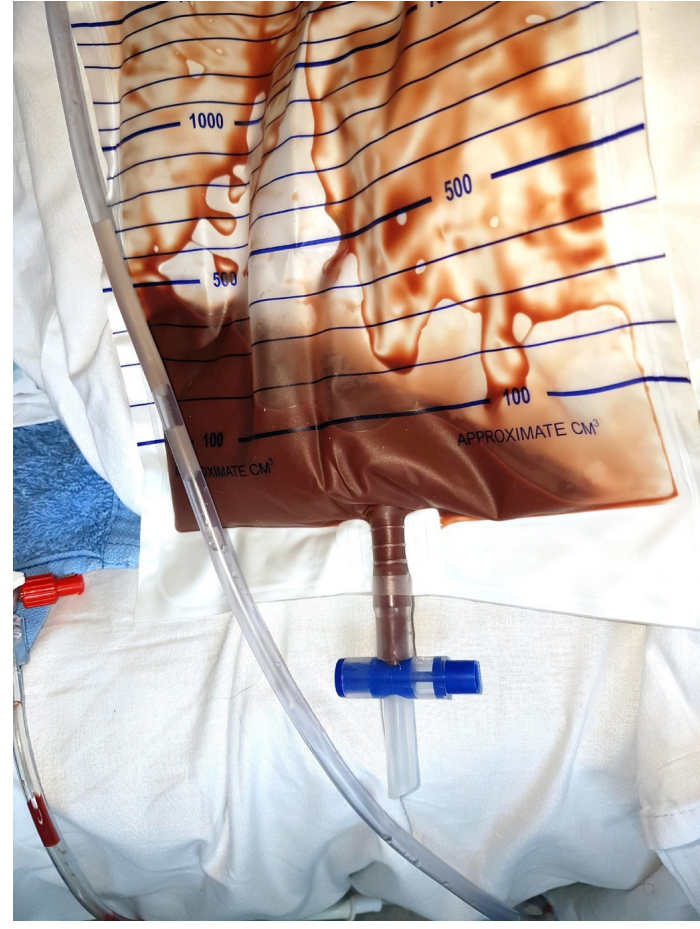

Figure 2 'Chocolate-like' liquid coming from the percutaneous drainage of the liver abscess.

\section{Learning points}

- Hepatic abscess in a patient returning from a tropical zone evokes Entamoeba histolytica abscess.

- Importance of aspiration for abscesses greater than $5 \mathrm{~cm}$. In amoebic abscess, liquid has usually a brown appearance, chocolate-like.

- Treatment consists in metronidazole for trophozoites $(500 \mathrm{mg}$ three times a day for 10 days) and paromomycin for cystic forms ( $500 \mathrm{mg}$ four times a day) during 7 days.

Contributors Dr TR and Dr LP contributed equally to the writing and the management of the patient. Dr HY and Professor BV helped in the writing and the management of the patient.

Competing interests None declared.

Patient consent Obtained.

Provenance and peer review Not commissioned; externally peer reviewed.

(c) BMJ Publishing Group Ltd (unless otherwise stated in the text of the article) 2017. All rights reserved. No commercial use is permitted unless otherwise expressly granted.

\section{REFERENCES}

1 Stanley SL. Amoebiasis. The Lancet 2003;361:1025-34.

2 Lübbert C, Wiegand J, Karlas T. Therapy of liver abscesses. Viszeralmedizin 2014;30:334-41. 
Copyright 2017 BMJ Publishing Group. All rights reserved. For permission to reuse any of this content visit http://group.bmj.com/group/rights-licensing/permissions.

BMJ Case Report Fellows may re-use this article for personal use and teaching without any further permission.

Become a Fellow of BMJ Case Reports today and you can:

- Submit as many cases as you like

- Enjoy fast sympathetic peer review and rapid publication of accepted articles

Access all the published articles

- Re-use any of the published material for personal use and teaching without further permission

For information on Institutional Fellowships contact consortiasales@bmjgroup.com

Visit casereports.bmj.com for more articles like this and to become a Fellow 